\title{
Resident trainees do not affect patient satisfaction in an outpatient gastroenterology clinic: A prospective study conducted in a Canadian gastroenterology clinic
}

\author{
Mayur Brahmania MD FRCPC, Madison Young MD, Chetty Muthiah MD FRCPC, Alexandra Ilnyckyj MD FRCPC, \\ Donald Duerksen MD FRCPC, Dana C Moffatt MD FRCPC
}

M Brahmania, M Young, C Muthiah, A Ilnyckyj, D Duerksen, DC Moffatt. Resident trainees do not affect patient satisfaction in an outpatient gastroenterology clinic: A prospective study conducted in a Canadian gastroenterology clinic. Can J Gastroenterol Hepatol 2015;29(7):363-368.

BACKGROUND: There is little literature regarding how a gastroenterology trainee affects a patient's interpretation of care during outpatient clinic visits. Improving patient satisfaction is desirable and benefits may include enhanced patient compliance as well as providing trainees with areas for improvement.

OBJECTIVES: To evaluate patient satisfaction in an outpatient gastroenterology clinic when seen by a trainee and attending physician versus an attending physician alone. The secondary objective was to evaluate physician characteristics that play a role in creating a positive clinical experience.

METHODS: A randomized prospective survey study was conducted over an 11-month period (July 2012 to June 2013) at St Boniface Hospital (Winnipeg, Manitoba). Two gastroenterology fellows (postgraduate year 4 and 5) and nine internal medicine residents (postgraduate year 1 to 3 ) comprised the 'trainee' role, while three academic clinicians comprised the 'attending' role. Patients included individuals seen for an initial consultation and were $>18$ years of age.

RESULTS: A total of 211 patients comprised the final study group, with 118 in the attending group and 93 in the trainee group. In univariate analysis, patients more often had a very good experience when seen by an attending physician alone versus a trainee and attending physician $(73 \%$ versus $56 \%$; $\mathrm{P}=0.016)$; however, on multivariate analysis, there was no significant difference in patient satisfaction (OR 0.89; $\mathrm{P}=0.931$ ). Physician factors found to be associated with high patient satisfaction on multivariate analysis included: addressing all patient concerns ( $\mathrm{OR} 27.56 ; \mathrm{P}=0.021)$; giving the patient a preliminary diagnosis ( $\mathrm{OR} 78.02 ; \mathrm{P}=0.006)$; and feeling the physician was thorough (OR 72.53; $\mathrm{P}=0.029$ ).

CONCLUSIONS: The present study did not reveal a difference in patient satisfaction if a patient sees an attending physician alone or with a trainee. Moreover, to improve patient satisfaction in a gastroenterology clinic, physicians should address all patient concerns, provide a preliminary diagnosis and appear to be thorough in their assessment. Further work to increase patient awareness on the role of residents in teaching hospitals is warranted to further promote careers in gastroenterology.

Key Words: Gastroenterology residents; Health care quality; Medical education; Patient care; Patient satisfaction
Les résidents ne nuisent pas à la satisfaction des patients dans une clinique ambulatoire de gastroentérologie : une étude prospective au sein d'une clinique canadienne de gastroentérologie

HISTORIQUE : Peu de publications scientifiques portent sur l'effet qu'ont les stagiaires en gastroentérologie sur l'interprétation que les patients se font des soins lors de leur rendez-vous ambulatoire. Il est souhaitable d'améliorer la satisfaction des patients, ce qui peut favoriser une meilleure adhésion au traitement et la transmission de conseils aux stagiaires pour qu'ils s'améliorent.

OBJECTIFS : Évaluer la satisfaction des patients dans une clinique de gastroentérologie ambulatoire lorsqu'ils sont vus par un stagiaire et un médecin ou par un médecin seulement. L'objectif secondaire consistait à évaluer les caractéristiques du médecin qui contribuaient à une expérience clinique positive.

MÉTHODOLOGIE : Les chercheurs ont réalisé une étude prospective aléatoire d'une durée de 11 mois (juillet 2012 à juin 2013) à l'Hôpital Saint-Boniface de Winnipeg, au Manitoba. Deux aspirants spécialistes en gastroentérologie (en $4^{\mathrm{e}}$ et $5^{\mathrm{e}}$ année) et neuf résidents en médecine interne (de $1^{\text {re }}$ à $3^{\mathrm{e}}$ année) représentaient les stagiaires, et trois cliniciens universitaires, les médecins. Les patients, qui avaient tous plus de 18 ans, étaient vus pour une première consultation.

RÉSULTATS : Au total, 211 patients ont formé les groupes d'étude définitifs, dont 118, le groupe du médecin, et 93, le groupe des stagiaires. À l'analyse univariée, les patients vivaient plus souvent une très bonne expérience auprès d'un médecin seul qu'auprès d'un stagiaire et un médecin ( $73 \%$ par rapport à $56 \% ; \mathrm{P}=0,016)$. Cependant, à l'analyse multivariée, on n'observait pas de différence significative en matière de satisfaction des patients ( $R R \quad 0,89 ; \mathrm{P}=0,931)$. Les facteurs liés aux médecins qui s'associaient à une forte satisfaction des patients à l'analyse multivariée incluaient la réponse à toutes les inquiétudes des patients ( $R R$ 27,56; $P=0,021$ ), la transmission d'un diagnostic préliminaire aux patients ( $R R 78,02 ; \mathrm{P}=0,006$ ) et l'impression que le médecin transmettait une évaluation approfondie ( $R R$ 72,53; $\mathrm{P}=0,029$ ).

CONCLUSIONS : La présente étude n'a pas révélé de différence dans la satisfaction des patients lorsqu'ils voient un médecin ou un médecin et un stagiaire. Pour accroître la satisfaction des patients à la clinique de gastroentérologie, les médecins devraient répondre à toutes les inquiétudes des patients, fournir un diagnostic préliminaire et sembler effectuer une évaluation approfondie. Des mesures s'imposent pour mieux sensibiliser les patients au rôle des résidents dans les hôpitaux universitaires afin de promouvoir des carrières en gastroentérologie.

factors and meeting patient expectations. Improving patient satisfaction has desirable effects such as reducing complaints, enhancing compliance and preventing recurrent physician visits (1-4). The field of

1 to improve clinical effectiveness. However, patient satisfaction influenced by many factors including technical factors, interpersonal

Department of Medicine, Division of Gastroenterology, University of Manitoba, St Boniface Hospital, Winnipeg, Manitoba

Correspondence: Dr Mayur Brahmania, Department of Medicine, Division of Gastroenterology, University of Manitoba, 804F-175 McDermot Avenue,

Winnipeg, Manitoba R3E 3P4. Telephone 204-789-3369, fax 204-789-3972, e-mail mbrahmania@gmail.com

Received for publication September 30, 2014. Accepted March 17, 2015 
gastroenterology (GI) incorporates both office- and procedure-based patient contact. To date, most studies have focused on enhancing patient satisfaction in the procedural component of the specialty focusing on endoscopy, purgatives and sedation techniques (5-7). Although these areas are continually evolving, GI outpatient clinics provide another area in which patient satisfaction initiatives can be undertaken. Recently, Larkin et al (8) showed that patient satisfaction in a GI clinic was highest when the physician was deemed to be a good listener and an effective treatment plan was explained. Interestingly, long wait times before the visit and clinic esthetics had no effect on overall satisfaction. Currently, there are no studies investigating the influence trainees have on patient satisfaction in an outpatient GI clinic. The education of GI trainees is key to developing future health care professionals who can continue research, education and care for the aging population. Thus, it would be beneficial for training programs to be aware of elements of care in which a trainee's education can improve and also possibly identify patient needs during consultation. Accordingly, the primary objective of our study was to evaluate patient satisfaction in an outpatient GI clinic when seen by a trainee and attending physician compared with an attending physician alone. Our secondary objective was to determine physician characteristics that play a role in patient satisfaction in a GI clinic.

\section{METHODS}

\section{Patients and definitions}

The present analysis was a prospective single-blinded study conducted at St Boniface Hospital, a tertiary care centre, located in Winnipeg, Manitoba, over an 11-month period (July 2012 to June 2013). The clinic is an outpatient facility for university-based resident teaching and clinical care. The study was conducted over a 120 -day clinic period. Eleven trainees, including two GI fellows (postgraduate year [PGY] 4 and 5) and nine internal medicine residents (three PGY 1, three PGY 2 and three PGY 3) comprised the 'trainee' population. The GI fellows each had one half-day clinic per week, and internal medicine residents on GI rotation attended two half-day clinics per week. All academic clinicians at the hospital $(n=3)$ participated in the present study comprising the 'attending' role. The Canadian health care system has no merit-based compensation programs and, thus, no specific information regarding a specific attending or trainee satisfaction score was gathered. The trainee or attending physician saw patients in chronological order based on appointment time. In other words, no discrimination regarding the type of case (ie, irritable bowel syndrome or celiac disease) or patient characteristic, etc, seen by a trainee was made. Trainees initially saw the patient individually and recommended their impressions and plans to the patient. Trainees then reviewed care plans with the attending physician in a separate private room, and both parties would then proceed to reaffirm the trainees plan or further clarify the history, physical examination or management plan. The attending physician would move on to see the next patient if the trainee was still in consultation to continue clinic flow.

Participation was entirely voluntary and, if agreeable, a survey was provided by the scheduling assistant after consultation. Patients were offered enrollment sequentially from July 2012 to June 2013. Attending physicians and trainees were blinded to patient participation, and results were kept confidential and anonymous. No deviation from normal care was undertaken if the patient was enrolled in the study. Attending physicians and trainees were not aware of the components of the survey aside from two of the authors (MB [trainee], DM [attending]). Incomplete surveys were counted as a refusal to participate. Patients included those seen for an initial consultation and were $>18$ years of age. Exclusion criteria included patients being seen for follow-up, and those with physical or intellectual disabilities that would make the survey difficult to complete. Demographic characteristics, such as age, sex, education level and location of residence, were gathered in addition to factors related to the clinic experience (time in waiting room, experience with booking clerk, time from referral to consultation, etc).

\section{Survey components}

In 1999, the Accreditation Council for Graduate Medical Education (ACGME) established the 'general competencies' for patient care. These included domains of patient care, medical knowledge, practicebased learning and improvement, interpersonal and communication skills, professionalism and systems-based practice. The ACGME competency mandate requires all residency programs to train and evaluate resident performance in these areas (9). Similarly, in 2005, the Royal College of Physicians and Surgeons of Canada developed a framework (CanMEDS) based on seven roles that all physicians must embody to be the 'ideal' physician. Areas included: Medical Expert, Communicator, Collaborator, Manager, Health Advocate, Scholar and Professional. These seven roles are also used to train and evaluate residents and medical students in all realms of medicine in Canada (10). The authors developed their own GI-specific survey (Appendix 1) incorporating the key features of the ACGME/ CanMEDS roles, reflecting the ideal qualities in a physician as well as questions adapted from subsections of three standardized patient satisfaction surveys that have been previously validated: the Patient Satisfaction Questionnaire Short-Form (PSQ-18) developed by the RAND Corporation (The RAND Corporation is a nonprofit institution that helps improve policy and decision making through research and analysis) (11); the Consumer Assessment of Health Plans Survey originally commissioned by the Agency for Healthcare Research and Quality (12); and the Visit Specific Satisfaction Questionnaire-9 (VSQ-9) (13). Questions from these surveys formed the body of the study that was of primary interest. Answers were recorded using a five-point Likert scale or in yes/no format primarily to encourage participation by offering an easy and quick survey acknowledging many patients are returning to work, paying for metered parking or trying to meet other appointments. The study received Research Ethics Board approval from the University of Manitoba and St Boniface Hospital, and was conducted in accordance with all national and institutional guidelines. No external funding was obtained for the present study.

\section{Statistical analysis}

Descriptive statistics used frequencies and percentages for the survey questions. Survey responses of the two groups were compared using a Mann-Whitney $U$ test for ordinal variables and a $\chi^{2}$ test for nonordinal variables. To investigate predictors of patient satisfaction, multivariate logistic regression was used. Six potential predictors of patient satisfaction in the logistic regression model were examined: time spent with the patient, all concerns and questions addressed, receiving an adequate diagnosis and explanation, confidence in physician, perceived competence of physician and perceived thoroughness of physician. Finally, to investigate whether patient satisfaction differed between the groups after accounting for the effect of the six predictors, a final ordinal logistic regression model that included a term for the group effect as well as the potential predictors was examined. In addition to these variables of interest, all models adjusted for patient characteristics including age, sex and education. All $\mathrm{P}$ values were two-sided; statistical significance was defined as $\mathrm{P}<0.05$. Data were analyzed using the $\mathrm{R}$ statistical software version 2.14.1 (R, USA).

\section{RESULTS}

\section{Baseline demographics and patient characteristics}

A total of 272 patients volunteered to complete the survey after initial consultation. Sixty-one patient surveys were excluded due to incomplete responses (ie, $\geq 1$ question[s] not answered). Of the 61 incomplete surveys, 27 were from the attending group and 34 were from the attending and trainee group $(\mathrm{P}>0.05)$. A total of 211 patients comprised the final study group, with 118 in the attending group and 93 in the trainee group (Figure 1).

Table 1 highlights patient characteristics. There was a significant difference in age, with the attending group seeing a higher percentage of patients who were $>65$ years of age ( $19 \%$ versus $11 \%$ ) and between the 46 and 55 years of age (30\% versus 16\%), while the trainee and 


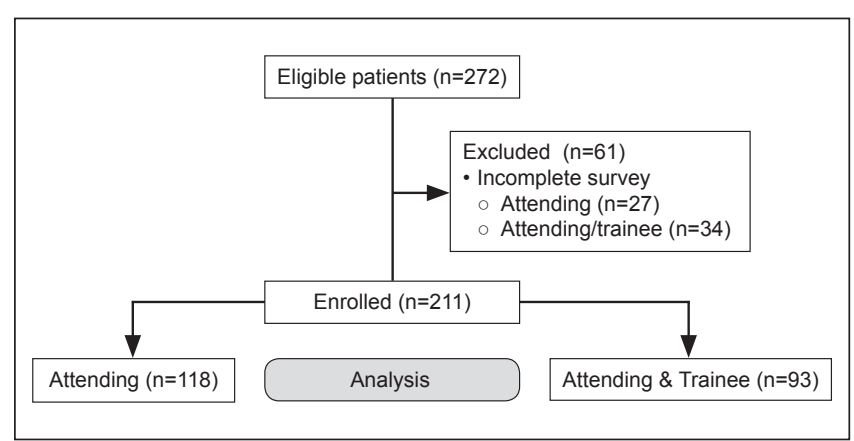

Figure 1) Patient enrollment

TABLE 1

Baseline demographics and patient characteristics

\begin{tabular}{|c|c|c|c|}
\hline \multirow[b]{2}{*}{ Characteristic } & \multicolumn{2}{|c|}{ Physician } & \multirow[b]{2}{*}{$\mathbf{P}^{*}$} \\
\hline & $\begin{array}{l}\text { Attending } \\
(n=118)\end{array}$ & $\begin{array}{l}\text { Trainee/ } \\
\text { attending } \\
(n=93)\end{array}$ & \\
\hline \multicolumn{4}{|l|}{ Age, years } \\
\hline $18-25$ & $16(14)$ & $12(13)$ & 0.019 \\
\hline $26-35$ & $12(10)$ & $21(23)$ & \\
\hline $36-45$ & $19(16)$ & $24(26)$ & \\
\hline $46-55$ & $35(30)$ & $15(16)$ & \\
\hline $56-65$ & $14(12)$ & $11(12)$ & \\
\hline$>65$ & $22(19)$ & $10(11)$ & \\
\hline Male sex, \% & 37.9 & 40.2 & 0.88 \\
\hline Residence (Winnipeg, Manitoba) & $84(71)$ & $79(85)$ & 0.018 \\
\hline \multicolumn{4}{|l|}{ Education } \\
\hline Elementary school & $4(3)$ & $0(0)$ & 0.001 \\
\hline High school & $45(38)$ & $23(25)$ & \\
\hline Some postsecondary & $37(31)$ & $24(26)$ & \\
\hline University/college degree & $27(23)$ & $40(43)$ & \\
\hline Postgraduate degree & $5(4)$ & $6(6)$ & \\
\hline Referral by family physician & $38(32)$ & $20(22)$ & 0.084 \\
\hline \multicolumn{4}{|l|}{ Time to consult, months } \\
\hline$<1$ & $17(14)$ & $10(11)$ & 0.453 \\
\hline 3 & $40(34)$ & $29(31)$ & \\
\hline 6 & $38(32)$ & $35(38)$ & \\
\hline 9 & $13(11)$ & $14(15)$ & \\
\hline$>12$ & $10(8)$ & $5(5)$ & \\
\hline \multicolumn{4}{|l|}{ Duration of symptoms, months } \\
\hline$<1$ & $9(8)$ & $9(10)$ & 0.301 \\
\hline 3 & $10(8)$ & $6(6)$ & \\
\hline 6 & $16(14)$ & $11(12)$ & \\
\hline 9 & $15(13)$ & $4(4)$ & \\
\hline$>12$ & $68(58)$ & $63(68)$ & \\
\hline
\end{tabular}

Data presented as $n(\%)$ unless otherwise indicated. ${ }^{*}$ Mann-Whitney U-test for ordinal variables and $\chi^{2}$ test for categorical variables

attending group saw patients between 26 and 35 (23\% versus 10\%) and 36 and 45 years of age ( $26 \%$ versus $16 \%)(\mathrm{P}=0.019)$. There was also a significant difference in place of residence because the trainee and attending groups saw patients from Winnipeg at a greater percentage $(85 \%$ versus $71 \%)(P=0.018)$. Education level was also significantly different between the two groups, with the trainee and attending group seeing patients who had some university/college degree (43\% versus $23 \%$ ), while the attending group saw more patients that had some high school education (38\% versus $25 \%$ ) $(\mathrm{P}=0.001)$. There were no differences between the two groups in referral pattern according to general practitioner $(\mathrm{P}=0.084)$, time to consult $(\mathrm{P}=0.453)$ and duration of symptoms $(\mathrm{P}=0.301)$.
TABLE 2

Univariate analysis of effect of trainee on patient satisfaction

\begin{tabular}{lccc} 
& \multicolumn{3}{c}{ Physician } \\
\cline { 2 - 3 } & $\begin{array}{c}\text { Traineel } \\
\text { Attending } \\
\text { (n=118) }\end{array}$ & $\begin{array}{c}\text { attending } \\
\text { (n=93) }\end{array}$ & P* \\
\hline Overall patient satisfaction & & & \\
Not good whatsoever & $0(0)$ & $1(1)$ & 0.016 \\
Bad & $2(2)$ & $1(1)$ & \\
Neutral & $7(6)$ & $7(8)$ & \\
Good & $23(19)$ & $32(34)$ & \\
Very good & $86(73)$ & $52(56)$ & \\
Patient has an idea of the cause of symptom & & & \\
Not at all & $46(39)$ & $25(27)$ & 0.051 \\
Not much & $18(15)$ & $12(13)$ & \\
Not sure & $24(20)$ & $24(26)$ & \\
A bit & $12(10)$ & $15(16)$ & \\
Yes & $18(15)$ & $17(18)$ & \\
Time spent with patient, min & & & \\
S5 & $3(3)$ & $1(1)$ & $<0.001$ \\
10 & $24(20)$ & $8(9)$ & \\
15 & $41(35)$ & $20(22)$ & \\
20 & $32(27)$ & $30(32)$ & \\
$\geq 25$ & $18(15)$ & $34(37)$ & \\
Greeted appropriately & $117(99)$ & $91(98)$ & 0.427 \\
Physician introduction & $117(99)$ & $90(97)$ & 0.209 \\
Physician role explained & $112(95)$ & $81(87)$ & 0.044 \\
Physician could have spent more & $6(5)$ & $3(3)$ & 0.507 \\
time with you & & & \\
Would return to clinic (yes) & $115(97)$ & $91(98)$ & 0.853 \\
\hline
\end{tabular}

Data presented as $n$ (\%) unless otherwise indicated. *Mann-Whitney U-test for ordinal variables and $\chi^{2}$ test for categorical variables

Patients reported a higher level of 'very good' overall patient satisfaction when seen by an attending alone versus an attending and trainee ( $73 \%$ versus $56 \%)(\mathrm{P}=0.016)$ (Table 2$)$. Conversely, patients reported a higher level of 'good' overall patient satisfaction when seen by an attending and trainee versus attending physician alone (34\% versus $19 \%$ ). Patients had neutral, bad or not good-at-all experiences $<10 \%$ of the time during the study period. Time spent with the patient was also significantly different between the two groups, with the trainee/attending group spending a greater proportion of time $>25 \mathrm{~min}$ with a patient ( $37 \%$ versus $15 \%)(\mathrm{P} \leq 0.001)$. In both groups, at least $98 \%$ of patients were greeted appropriately, $95 \%$ were satisfied with the time physicians spent with them, and at least $97 \%$ of patients would return for clinic follow-up.

In multivariate analysis, three variables were associated with overall patient satisfaction: addressing all patient concerns (OR 27.56; $\mathrm{P}=0.021$ ) (Table 3 ), giving the patient a preliminary diagnosis (OR 78.02; $\mathrm{P} \leq 0.006)$ and feeling the physician was thorough with the evaluation ( $\mathrm{OR}$ 72.53; $\mathrm{P}=0.029$ ). After accounting for the six variables chosen on physician characteristics (time spent, confidence, competence, addressing concerns, giving a diagnosis and being thorough), patient satisfaction was no different when seen by an attending alone versus attending and trainee (OR 0.89; $\mathrm{P}=0.931)$ (Table 3).

\section{DISCUSSION}

The importance of patient satisfaction has been previously shown to improve compliance with treatment and improved health outcomes (1-4). Satisfaction studies involving the endoscopic aspect of GI have found technical factors do not have a role in patient satisfaction, stressing the importance of communication and developing a therapeutic alliance with the patient (14-16). In our prospective study, we found no difference in patient satisfaction when seen by trainees and attending versus attending alone because most patients had a good to 


\begin{tabular}{|c|c|c|c|c|}
\hline \multirow[b]{2}{*}{ Predictor } & \multicolumn{2}{|l|}{ Model A ${ }^{\dagger}$} & \multicolumn{2}{|l|}{ Model $\mathrm{B}^{\ddagger}$} \\
\hline & OR $(95 \% \mathrm{Cl})$ & $\mathbf{P}$ & OR $(95 \% \mathrm{Cl})$ & $\mathbf{P}$ \\
\hline $\begin{array}{l}\text { Time spent } \\
\text { with patient }\end{array}$ & $0.46(0.04-5.56)$ & 0.536 & $0.49(0.03-7.69)$ & 0.611 \\
\hline $\begin{array}{l}\text { Confidence } \\
\text { in physician }\end{array}$ & $9.96(0.49-100)$ & 0.139 & $8.70(0.44-100)$ & 0.156 \\
\hline $\begin{array}{l}\text { Competence } \\
\text { in physician }\end{array}$ & $0.08(0-7.69)$ & 0.277 & $0.08(0-7.69)$ & 0.276 \\
\hline $\begin{array}{r}\text { All concerns } \\
\text { addressed }\end{array}$ & $27.56(1.67-458)$ & 0.021 & $27.33(1.64-454)$ & 0.021 \\
\hline $\begin{array}{l}\text { Given a preliminary } \\
\text { diagnosis }\end{array}$ & $78.02(3.45-1762)$ & 0.006 & 81.39 (3.07-2161) & 0.009 \\
\hline $\begin{array}{l}\text { Thoroughness } \\
\text { of physician }\end{array}$ & $72.53(1.56-3384)$ & 0.029 & $72.74(1.55-3415)$ & 0.029 \\
\hline $\begin{array}{l}\text { Group (trainee/ } \\
\text { attending versus } \\
\text { attending) }\end{array}$ & - & - & $0.89(0.06-13.74)$ & 0.931 \\
\hline
\end{tabular}

${ }^{*}$ Both models are adjusted for age, sex and education; ${ }^{\dagger}$ Model $A$ examines the predictors of increased patient satisfaction with clinical experience; $¥$ Model $B$ examines the group effect adjusting for all predictors in model $A$

very good experience (92\% attending versus $90 \%$ trainee and attending) with the consultation process. However, patients did rate their experience as 'very good' more often when seen by an attending physician alone; however, when the groups 'very good' and 'good' were grouped together in multivariate analysis, this difference between attending and trainee/attending was not apparent $(\mathrm{P}=0.931)$ (Table 3). The difference observed in univariate analysis may have been the result of the attending physicians seeing older, less educated patients and those from an area outside of our hospital's city, where physicians may be held in a higher social regard/authority. However, this was accounted for in our multivariate model and it did not remain statistically significant, suggesting an unmeasured variable accounting for this difference not captured by our quantitative survey-based analysis. As stated above, no special selection of patients occurred (ie, trainees seeing more interesting or less complex cases). If we are to believe that a difference exists between a 'very good' and 'good' consultation process, a set of criteria must be established to define this entity; however, this currently does not exist in any survey or quality benchmark and was not the purpose of our study. Nevertheless, we must acknowledge this difference and surmise the inexperience of trainees or personal manners may be playing a role, which has been previously been shown in a study by Yancy et al (17) and other studies (18-20) examining patient satisfaction in trainee ambulatory clinics not involving GI. Previous studies also have shown resident training level correlates with satisfaction, with junior residents scoring less than more senior residents. Reasons for this again include inexperience and the limited ability to deal with complex medical care seen in academic referral centres (21). In our study, we had PGY1 to PGY5 residents participating, and it is unclear whether junior residents had an effect because we could not account for this from our data due the survey design. If this were a significant issue, the difference between the trainee and attending group would have strengthened, which was not the case in our study.

Ways to improve trainee performance and enhance patient satisfaction have been studied using techniques such as receiving psychosocial training before patient care, enhancing supervision during important clinical decision-making time points and improving nonverbal communication styles (22-24). In our study, we found three factors significantly correlating with overall patient satisfaction (addressing patient concerns, providing a diagnosis and appearing to be thorough with the consultation). Therefore, most of the satisfaction patients derive from a physician visit relates to the history and physical examination rather than physician 'kindness', wait times or if the physician was punctual. These factors emphasize the value patients place on good communication skills. Interestingly, arriving at the 'correct' clinical diagnosis may not mean as much to patients as it does to the physician. However, helping patients understand their disease or reduce their anxiety may have its own therapeutic value. For example, providing a patient with a preliminary diagnosis (ie, "you most likely have irritable bowel syndrome" and addressing any concerns/questions a patient may have during consultation, ie, "Do I have cancer?" was strongly correlated with patient satisfaction (OR 27.56). This was independent of which provider group the patients had seen. This has important implications as training programs have to ensure trainees have sufficient knowledge to confidently deliver a diagnosis, relative to their training level and be able to acknowledge their limitations while aiming for high patient satisfaction.

We must stress that other important factors likely contribute to overall patient satisfaction and these may occur even before the patient sees a physician. In our study, we found significant correlations between the interactions with the booking clerk and overall satisfaction; however, in the multivariate model, these were not significant. This suggests that many factors contribute to creating a positive or negative experience in clinic and, of course, confounders outside of the scope of the present study undoubtedly impact patient satisfaction.

Our study had several limitations. First, two authors knew the components of the survey (one was an attending physician [DM] and the other a trainee $[\mathrm{MB}]$ ), which may have led to a change in clinician behaviour (ie, Hawthorne effect). However, sustaining a changed behaviour over a prolonged period would have been difficult and, given the relatively small size of our institution, the study design and concept would have been difficult to complete if we excluded physicians involved in the study design. Second, the study may have limited generalizability because patients were from one discipline (ie, GI); therefore, the results may not be generalizable to other specialties. However, given that patients seen in this clinic were referred from primary care community physicians, we believe these results would likely be similar at other university-based residency programs with trainee clinics, irrespective of location/specialty. Third, although our survey has not been validated in other studies, we believe that no optimal questionnaire existed to answer what patient satisfaction meant to the patient; therefore, we developed our own questionnaire using components of the ACGME/CanMEDs and above-mentioned questionnaires. A future prospective study validating the study is ongoing. Finally, almost all patients were satisfied or very satisfied, raising the question as to whether selection bias occurred and unsatisfied patients refused to complete the questionnaire. However, if a patient was unsatisfied, the survey would have provided an opportunity to express these concerns or negative feelings in an anonymous fashion because surveys were completed in a private area and an area for free-text comments was also offered. Conversely, it is possible that a 'social-desirability bias' occurred and patients were attempting to 'please' the physicians and trainees by giving generally positive scores (25). We did attempt to limit these types of bias by assuring patient confidentiality and by giving surveys after the consult. We acknowledge the predictors of overall satisfaction we found (ie, addressing patient concerns, etc) could actually be considered an individual component of satisfaction, thus, they may be ultimately correlated with 'overall' satisfaction.

\section{CONCLUSION}

In the present study, we identified specific elements of the physician patient interaction appearing to improve patient satisfaction during a first GI consultation. Addressing all patient concerns and providing a preliminary diagnosis while appearing thorough in the consultation process all contribute to a positive patient experience. Further work in validating a GI-specific patient satisfaction survey is needed; however, trainees should be reminded the emphasis on patient care is solely not on the medical management of disease but also the social aspects the patient's life. Our study showed that GI trainees do not affect patient satisfaction in GI clinics and, thus, gastroenterologists should welcome trainees into routine clinical practice to enhance learning while also promoting interest in GI. 
ACKNOWLEDGEMENTS: The authors thank Angela Vandendrissche for data collection and Matt Kowgier for statistical analysis.

FUNDING: This study was internally funded.

DISCLOSURES: The authors have no financial disclosures or conflicts of interest to declare.

AUTHOR CONTRIBUTIONS: Mayur Brahmania: study concept and design; acquisition of data; analysis and interpretation of data; drafting of the manuscript; critical revision of the manuscript for important intellectual content; statistical analysis; administrative, technical or material support; study supervision). Madison Young: acquisition of data; analysis and interpretation of data). Chetty Muthiah: study concept and design; drafting of the manuscript; critical revision of the manuscript for important intellectual content; statistical analysis. Alexandra Ilnyckyj: critical revision of the manuscript for important intellectual content. Donald Duerksen: critical revision of the manuscript for important intellectual content. Dana Moffatt: study concept and design; acquisition of data; analysis and interpretation of data; drafting of the manuscript; critical revision of the manuscript for important intellectual content; statistical analysis; administrative, technical or material support; study supervision.

\section{APPENDIX 1}

\section{SECTION 1 - PATIENT DEMOGRAPHICS}

Please mark the appropriate box for each question or fill in the blank where needed 1. Age
$\square$ 18-25
$26-35$
$36-45$
$\square 46-55$
$\square$ 56-65
$\square>65$

2. Gender
$\square$ Female
$\square$ Male

3. Highest education level

$\square$ Elementary School

$\square$ High School

$\square$ Some Post Secondary Education

$\square$ University/College Degree

$\square$ Post Graduate Degree

4. Marital status
$\square$ Single
$\square$ Married
$\square$ Divorced
$\square$ Widowed
Common law

5. City of residence:

$\square$ Winnipeg $\square$ Other

\section{SECTION 2 - CLINIC EXPERIENCE}

1. Did you get parking easily? (please check one)

$\square$ Yes $\square$ No

2. How would you rate your experience with the booking clerk?
1
2
3
4
Very Pleasant
Not Pleasant

3. For how long did you have your gastrointestinal symptoms/problem before you saw the doctor?

$\begin{array}{lrrrr}1 & 2 & 3 & 4 & 5 \\ <1 \mathrm{mo} & 3 \mathrm{mo} & 6 \mathrm{mo} & 9 \mathrm{mo} & >1 \text { year }\end{array}$

4. Do you have an idea about the cause of your gastrointestinal symptoms/problem?
12
3
4
5
Not at all
$2-3$
Yes

5. Who referred you to the GI specialist?

$\square$ Family Doctor $\square$ Nurse practitioner

Another specialist

6. How long did you wait for this appointment after the referral?

$\begin{array}{lrrrr}1 & 2 & 3 & 4 & 5 \\ <1 \mathrm{mo} & 3 \mathrm{mo} & 6 \mathrm{mo} & 9 \mathrm{mo} & >1 \text { year }\end{array}$

7. How long was your wait in the clinic today prior to seeing the doctor?

$\begin{array}{lcccr}1 & 2 & 3 & 4 & 5 \\ <5 \mathrm{~min} & 15 \mathrm{~min} & 30 \mathrm{~min} & 45 \mathrm{~min} & >1 \mathrm{hr}\end{array}$

8. How long was your trip to the hospital clinic?

$\begin{array}{lcccr}1 & 2 & 3 & 4 & 5 \\ <5 \mathrm{~min} & 15 \mathrm{~min} & 30 \mathrm{~min} & 45 \mathrm{~min} & >1 \mathrm{hr}\end{array}$

\section{SECTION 3 - DOCTOR EXPERIENCE}

Which physician(s) did you see in the clinic? (please check one)

$\square$ Gastroenterologist (1 doctor) - If seen by one doctor, go to section 3A

$\square$ Gastroenterologist and Trainee (2 doctors) - If seen by two doctors, go to section $3 \mathrm{~B}$

\section{SECTION 3A - DOCTOR ONLY EXPERIENCE}

(Please fill in this section if you were seen by one doctor only)

1. How much time did the doctor spend with you?

$<5$ min $10 \mathrm{~min} \quad 15 \mathrm{~min} \quad 20 \mathrm{~min} \quad>25 \mathrm{~min}$

2. Were you and family/friends greeted appropriately?

$\square$ Yes $\square$ No

3. Did the doctor introduce her/himself appropriately?

$\square$ Yes $\square$ No

4. Did the doctor explain her/his role to you?

$\square$ Yes $\square$ No

5. Were your questions/concerns addressed?

$\begin{array}{lrrrr}1 & 2 & 3 & 4 & 5 \\ \text { None were addressed } & & \text { All concerns addressed }\end{array}$

6. Do you feel that the doctor could have spent more time with you? $\square$ Yes $\square$ No

IF Yes: How much more time would be reasonable

7. Were you given a diagnosis or explanation of the possible causes of symptoms and was it explained well to you?

$\begin{array}{llllr}1 & 3 & 3 & 4 & 5 \\ \text { No diagnosis/Not explained } & & & \text { Well explained }\end{array}$

8. How satisfied were you with your overall experience with the doctor?

$\begin{array}{lrrrr}1 & 3 & 3 & 4 & 5 \\ \text { Not satisfied at all } & & & \text { Very satisfied }\end{array}$

9. How confident do you feel with the doctor's diagnosis/management plan?
12
3
4
Very confident

10. How competent do you feel the doctor was?
12
3
4
Very competent
Not competent at all

11. How thorough do you feel the doctor was?
1
3
Not thorough at all
45
Very thorough

12. Would you return to this clinic?

$\square$ Yes $\square$ No

13. How was your experience overall?
1
2
Not good at all
4
5
Very good

\section{SECTION 3B - DOCTOR AND TRAINEE EXPERIENCE}

(Please fill in this section if you were seen by two doctors)

1. How much time did the trainee and doctor spend with you?

$<5$ min $10 \mathrm{~min} \quad 15 \mathrm{~min} \quad 20 \mathrm{~min} \quad>25 \mathrm{~min}$

2. Were you and family/friends greeted appropriately?

$\square$ Yes $\square$ No

3. Did the doctor and trainee introduce themselves appropriately? $\square$ Yes $\square$ No

4. Did the trainee and doctor explain their roles to you? $\square$ Yes $\square$ No 
5. Were your questions/concerns addressed?
1$$
2
$$$$
3
$$
4
5
None were addressed
All concerns addressed

6. Do you feel that the doctor and trainee could have spent more time with you?

$\square$ Yes $\square$ No

IF Yes: How much more time would be reasonable

7. Were you given a diagnosis or explanation of the possible causes of symptoms and was it explained well to you?
1
2
3
4
No diagnosis/Not explained
Well explained

8. Did the trainee's diagnosis differ from the gastroenterologist?

$\square$ Yes $\square$ No

9. How satisfied were you with your overall experience with the trainee and doctor?
1
3
4
Very satisfied
Not satisfied at all

10. How confident do you feel with the doctor's diagnosis/management plan?
$1 \quad 2$
3
Not confident at all
Very confident

\section{REFERENCES}

1. Frances V, Korsch BM, Morris MJ. Gaps in doctor-patient communications. N Engl J Med 1969;280:535-40.

2. Davis MS. Variation in patients' compliance with doctors' orders: Medical practice and doctor-patient interaction. Psychiatry Med 1971;2:31-54.

3. Kasteler J, Kane RL, Olsen DM, et al. Issues underlying prevalence of "doctor-shopping" behavior. J Health Soc Behav 1976;17:329-39.

4. Vaccarino JM. Malpractice: The problem in perspective. JAMA 1977;238:861-3.

5. Johnson DA, Barkun AN, Cohen LB, et al. US Multi-Society Task Force on Colorectal Cancer. Optimizing adequacy of bowel cleansing for colonoscopy: Recommendations from the US multi-society task force on colorectal cancer. Gastroenterology 2014;147:903-24.

6. Ko HH, Zhang H, Telford JJ, Enns R. Factors influencing patient satisfaction when undergoing endoscopic procedures. Gastrointest Endosc 2009;69:883-91.

7. Leffler DA, Bukoye B, Sawhney M, et al. Development and validation of the PROcedural Sedation Assessment Survey (PROSAS) for assessment of procedural sedation quality. Gastrointest Endosc 2015;81:194-203.

8. Larkins AS, Windsor AV, Trebble TM. An evaluation of patient attitudes to the gastroenterology outpatient experience. Eur J Gastroenterol Hepatol 2013;25:44-55.

9. Hechtel L, Chang T, Tseng E, et al. ACGME Outcome Project. Common Program Requirements: general competencies. February 2007. <www.acgme.org/outcome/comp/compCPRL.asp> (Accessed May 4, 2015).

10. Frank JR, ed. The CanMEDS 2005 Physician Competency Framework. Better standards. Better physicians. Better care. Ottawa: The Royal College of Physicians and Surgeons of Canada, 2005.

11. RAND Health. Patient satisfaction questionnaire. Instructions for scoring the PSQ-18. April 2007. <www.rand.org/health/surveys_ tools/psq/index.html> (Accessed May 4, 2015).

12. Consumer Assessment Surveys. Agency for Healthcare Research and Quality. September 2012. <https://cahps.ahrq.gov/surveysguidance/cg/visit/index.html> (Accessed May 4, 2015).

13. Davies AR, Ware JE. GHAA's Consumer Satisfaction Survey and User's Manual, 2nd edn. 1991.
11. How competent do you feel the trainee and doctor were?

$\begin{array}{rrrrr}1 & 2 & 3 & 4 & 5 \\ \text { Not competent at all } & & \text { Very competent }\end{array}$

12. How thorough do you feel the trainee and doctor were?
1
2
3
4
Very thorough
Not thorough at all

13. Would you return to this clinic?

$\square$ Yes $\square$ No

14. Would you like to have a trainee see you again prior to the doctor again if give the choice?

$\square$ Yes $\square$ No

15. How was your experience overall?

$\begin{array}{llrr}1 & 3 & 4 & 5 \\ \text { Not good at all } & & & \text { Very good }\end{array}$

\section{SECTION 4}

1. Any additional comments?

14. Jackson JL, Osgard E, Fincher RK. Resident participation in flexible sigmoidoscopy does not affect patient satisfaction.

Am J Gastroenterol 2000;95:1563-6.

15. Qureshi M, Shafqat F, Ahmed S, Niazi TK, Khokhar N. Factors affecting patient satisfaction during endoscopic procedures. J Coll Physicians Surg Pak 2013;23:775-9.

16. McEntire J1, Sahota J, Hydes T, Trebble TM. An evaluation of patient attitudes to colonoscopy and the importance of endoscopist interaction and the endoscopy environment to satisfaction and value. Scand J Gastroenterol 2013;48:366-73.

17. Yancy WS Jr, Macpherson DS, Hanusa BH, et al. Patient satisfaction in resident and attending ambulatory care clinics. J Gen Intern Med 2001;16:755-62.

18. Huynh M, Lee AD, Miller LM, Davis S, Feldman SR, McMichael A. Patients' satisfaction with dermatology residents. South Med J 2012;105:520-3.

19. Monk SM, Nanagas MT, Fitch JL, Stolfi A, Pickoff AS. Comparison of resident and faculty patient satisfaction surveys in a pediatric ambulatory clinic. Teach Learn Med 2006;18:343-7.

20. Issa MA, Kim CH. Patient satisfaction with residents vs. attending following fluoroscopy-guided pain injections. Pain Med 2012;13:185-9.

21. Nakar S, Levi D, Rosenberg R, Vinker S. Patient attitudes to being treated by junior residents in the community. Patient Educ Couns 2010;78:111-6.

22. Smith RC, Lyles JS, Mettler JA, et al. A strategy for improving patient satisfaction by the intensive training of residents in psychosocial medicine: A controlled, randomized study. Acad Med 1995;70:729-32.

23. Farnan JM, Petty LA, Georgitis E, et al. A systematic review: The effect of clinical supervision on patient and residency education outcomes. Acad Med 2012;87:428-42.

24. Griffith CH, Wilson JF, Langer S, Haist SA. House staff nonverbal communication skills and standardized patient satisfaction. J Gen Intern Med 2003;18:170-4.

25. Dalton D, Ortegren, M. Gender differences in ethics research: The importance of controlling for the social desirability response bias. J Business Ethics 2011;103:73-93. 


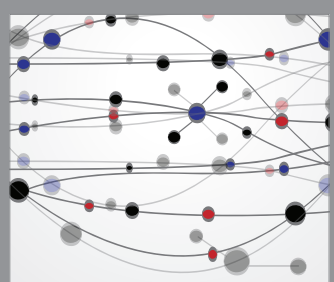

The Scientific World Journal
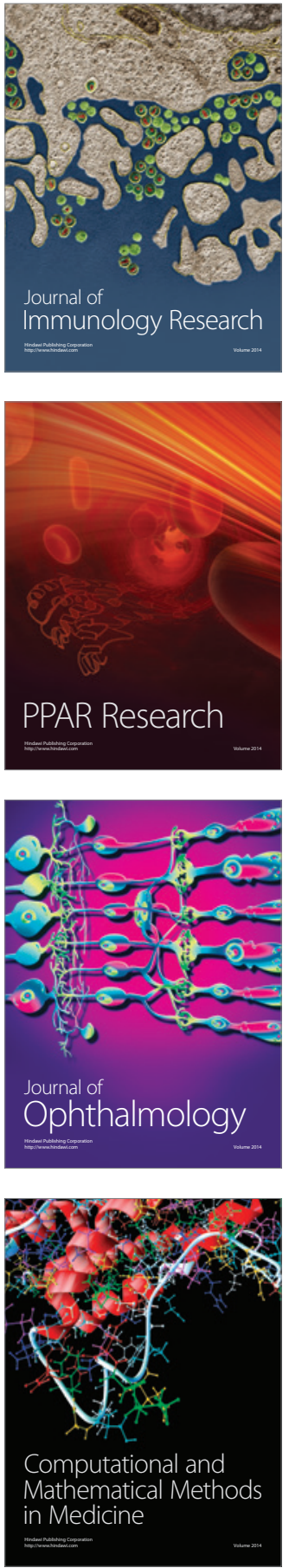

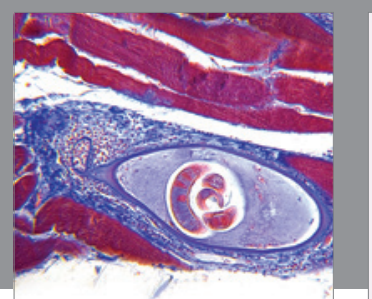

Gastroenterology Research and Practice

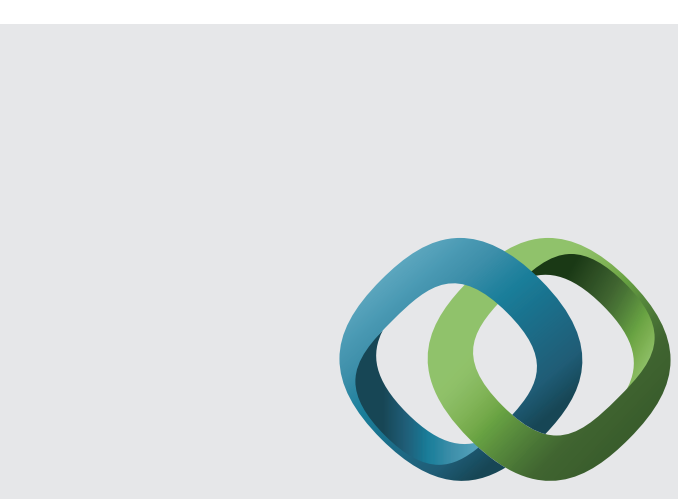

\section{Hindawi}

Submit your manuscripts at

http://www.hindawi.com
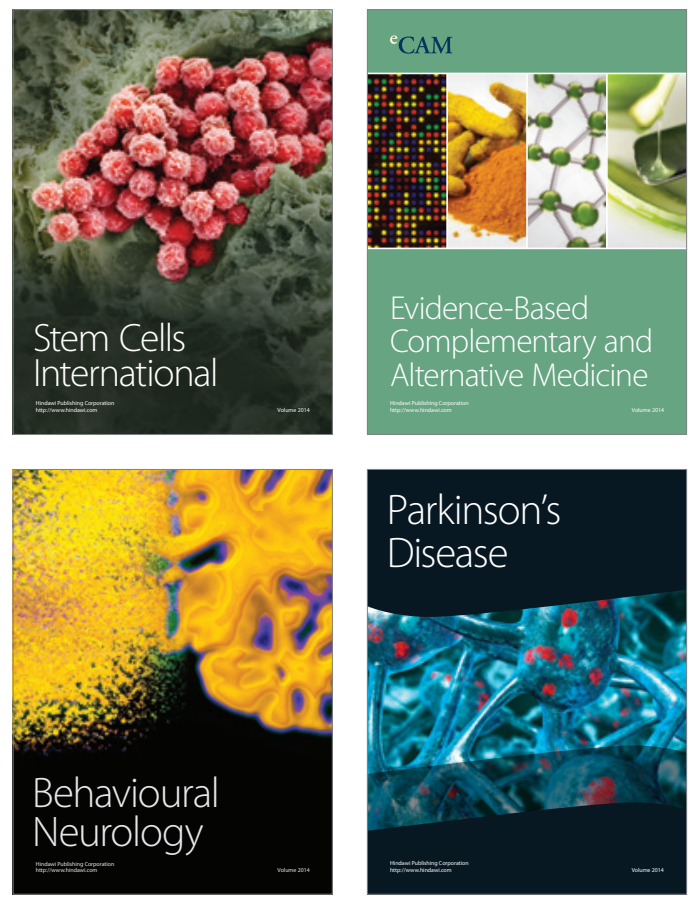
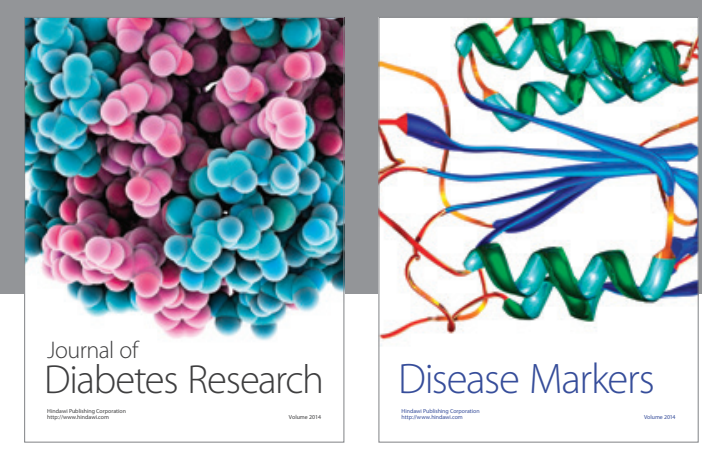

Disease Markers
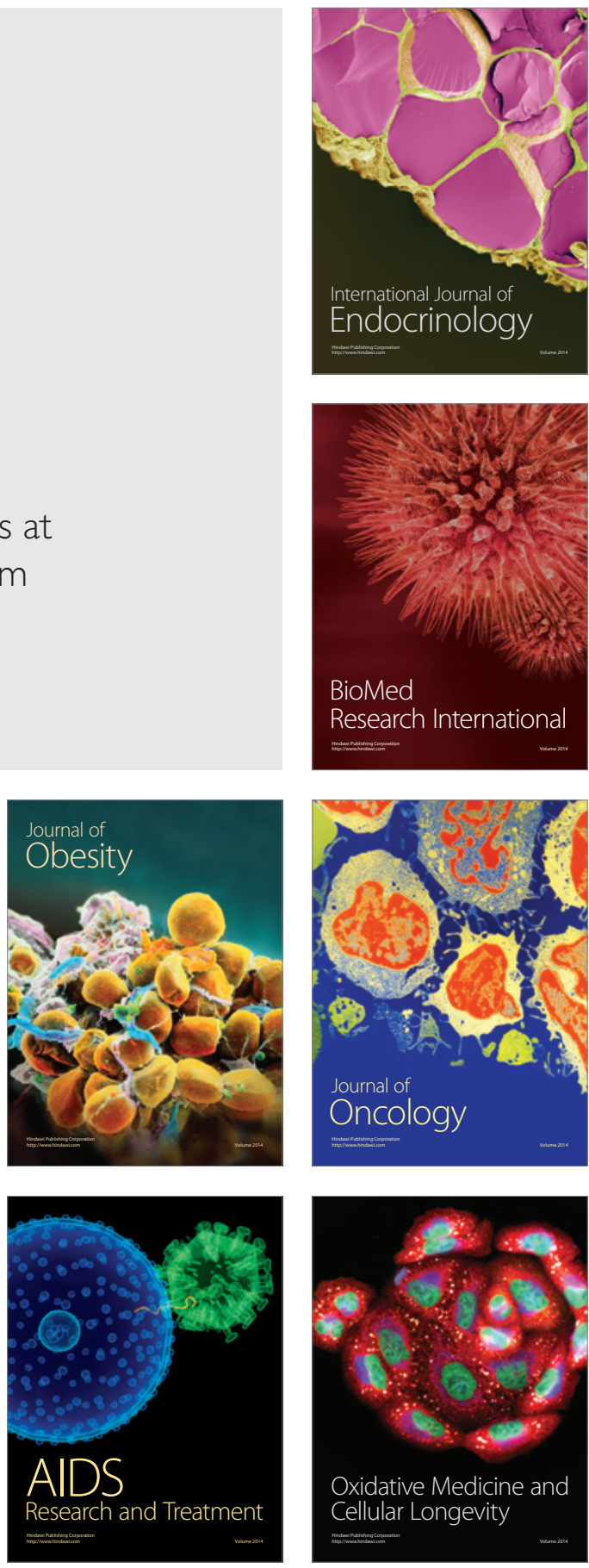